\title{
SPLITTING TWAIL?
}

\section{George R.B. Galindo*}

Periodizations are political acts. They produce temporalities that do not necessarily coincide with chronology. TWAIL (Third World Approaches to International Law) scholars have generally endorsed the division of TWAIL into two generations. Whereas TWAIL I was composed by scholars that thought and wrote about international law during the decolonization process, TWAIL II began at the end of the 1990s. Although there are common features between the generations, a number of differences are also identified and emphasized by TWAIL II scholars. In this article, I advance the argument that such periodization is problematic for four reasons: anachronism, progressivism, a difficult self-identification of past third world legal scholars with TWAIL and the image made of TWAIL by non-TWAILers. Instead of periodizing TWAIL in two successive generations, I argue that identifying it as part of a larger tradition of third world international legal scholarship is more productive for the inner coherence of the intellectual movement and, consequently, for its success in the international legal academia.

Périodisations sont des actes politiques. Ils produisent des temporalités qui ne coïncident pas nécessairement avec la chronologie. Les chercheurs des TWAIL (Third World Approches of International Law) ont généralement approuvé la division des TWAIL en deux générations. Considérant que les TWAIL I était composé par les savants qui pensaient et écrit sur le droit international pendant le processus de décolonisation, les TWAIL II a commencé à la fin des années 1990. Bien que l'on suppose qu'il y a des traits communs entre les générations, un certain nombre de différences sont également identifiés et souligné par les chercheurs des TWAIL II. Dans cet article, je avance l'argument que cette périodisation est problématique pour quatre raisons: l'anachronisme, progressisme, une auto-identification difficile des anciens juristes du tiers monde avec les TWAIL et l'image des TWAIL par des non-TWAILers. Au lieu de périodisation dans deux générations successives, je soutiens que l'identifiant comme partie d'une grande tradition juridique international du tiers monde est plus productif pour la cohérence interne de ce mouvement intellectuel et, par conséquent, de son succès dans le milieu universitaire juridique international.

Legal Advisor, Foreign Relations Ministry, Brazil. Professor, University of Brasília Law School (Brazil). I would like to thank Guilherme Del Negro, Patrícia Barros, Fabia Veçoso, Adriane Sanctis, Antony Anghie, Ralph Wilde, the participants of the TWAIL Conference "On Praxis and the Intellectual”, held in Cairo, 2015, and the TWAIL Writing Workshop, held in Windsor, 2015, as well as two anonymous reviewers of WYAJ. Their careful reading and extremely useful comments were essential for the drafting of this piece. The content of this article does not reflect the official opinion of the Brazilian Foreign Relations Ministry. Responsibility for the information and views expressed therein lies entirely with the author. 


\section{INTRODUCTION}

It is undeniable that TWAIL [Third World Approaches to International Law] has enormously matured as an intellectual movement in international legal studies. The growing number of publications, conferences and projects under its banner is noteworthy. ${ }^{1}$

Due to such maturity, it is not too early (or too late) to come back to TWAIL's theoretical, historical and methodological framework. Such an endeavour is not exactly new. Several articles published in recent years faced the challenge of depicting TWAIL's inner dimensions. ${ }^{2}$

However, in my vision, proper attention has barely been given to a fundamental aspect that entangles the theory, the history and the methodology of TWAIL: that of periodization. Trying to find a beginning for TWAIL is far from an act of merely situating a certain movement or tradition chronologically. Thus, periodization is "not simply the drawing of an arbitrary line through time, but a complex process of conceptualizing categories, which are posited as homogeneous and retroactively validated by the designation of a period divide." 3 Such conceptualization of categories invariably affects any theory, methodology or historical narrative supported by TWAIL scholars since the fixing of periods produces bias and reductions and can obliterate possibilities for the emergence of different perspectives. It is certain that periodization fulfills a heuristic function in the historian's craft (or anyone dealing with history); however, such function has unavoidable social and political implications.

In this way, periodization is an essential topic for TWAILers to understand how they situate and act in the stock market of international legal theories and methods. It is so essential that literary critics such as Frederic Jameson framed the maxim that "we cannot not periodize."4 Perhaps such a maxim is an exaggeration, or we at least should recognize that periodizations are contingent upon a certain (Western)

temporality. ${ }^{5}$ Be that as it may, we cannot deny periodizations have a definitive impact on the way we conceive of time - and also on the way we conceive of the time of TWAIL.

1 Gathii's article on the state of TWAIL scholarship, dated 2011, has already noticed the prolific character of TWAIL studies. See James Thuo Gathii, “TWAIL: A Brief History of its Origins, its Decentralized Network, and a Tentative Bibliography" (2011) 3 Trade L \& Dev 26.

2 Some, specifically concerned with the aforementioned aspects, might be recalled here, such as Obiora Okafor, "Critical Third World Approaches to International Law (TWAIL): Theory, Methodology or Both?" (2008) 10 Int'l Community LR 371, Ibironke T Odomusu, "Challenges for the (Present/) Future of Third World Approaches to International Law" (2008) 10 Intl Community LR 371, Gathii, supra note 1; and Karin Mickelson, "Rethinking Modes of Diffusion and Research and Teaching Methods: A TWAIL Perspective" in Mark Toufayan, Emmanuelle Tourme-Jouannet \& Hélène Ruiz Fabri, eds, Droit International et Nouvelles Approches sur le Tiers-Monde: Entre Répétition et Renouveau (Paris: Societé de Législation Comparée, 2013) 313 [Mickelson, "TWAIL Perspective"].

3 Kathleen Davis, Periodization and Sovereignty: How Ideas of Feudalism and Secularization Govern the Politics of Time (Philadelphia: University of Pennsylvania Press, 2008) at 3.

4 Frederic Jameson, A Singular Modernity: Essay on the Ontology of the Present (London: Verso, 2002) at 29-30.

5 On the relationship between periodization and different temporalities from a postcolonial perspective, see Nils Riecken, "Periodization and the Political: Abdallah Laroui's Analysis of Temporalities in a Postcolonial Context" (2012) ZMO Working Papers No. 6/2012, online: Deutsche National Bibliothek <http://d-nb.info/1026472040/34>. An intriguing

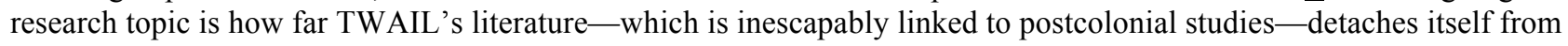
a Western notion of temporality. Unfortunately, we cannot deal with that topic since it is not the focus of this article. 
In this article, I will deal with the issue of TWAIL's own periodization in two generations: TWAIL I and TWAIL II. I will try to put into question such a well-established division. My main argument is that embracing such periodization may present risks for TWAIL being, to paraphrase Chimni, able to dent mainstream international law scholarship. ${ }^{6}$ TWAIL must be seen as an intellectual movement that is part of a long tradition and not as a succession of generations whose tempers, attitudes and priorities vary.

Investigating TWAIL's own politics of time is important, not only to open the possibility for new theoretical and methodological approaches; it also assists TWAIL achieve its goal of penetrating in the international legal mainstream discourse which is poorly informed by the priorities and the needs of third world states and peoples. Taking this into account, this investigation fulfills an ethical agenda that intends to put the third world at the centre of international law.

This article is divided into two parts. First, I will deal with the well-established division of TWAIL into two generations and the problems such a division creates. Second, I will sketch a proposal of a different way to situate TWAIL in time, namely within a tradition of international legal studies that can perhaps be traced since to at least the beginning of the erosion of the Colonial Powers. Such a proposal is undeniably a different periodization; however, it is one that maybe can help to make TWAIL voices more widely heard in international legal scholarship and elsewhere.

\section{TWAIL I, TWAIL II}

One of the TWAIL literature's main features is the insistence on the need for history to understand current international law. The first TWAIL pieces leave no doubt on such a need. ${ }^{7}$

In this regard, it is important to remember the beginning of TWAIL with that label can be traced to a gathering entitled "New Approaches to Third World Legal Studies", held at Harvard Law School in 1997. On the occasion, the participants wrote a vision statement in which the history of international law appeared in the very first paragraph: "[w]e understand the historical scope and agenda of the dominant voice of international law scholarship as having participated in, and legitimated global processes of marginalization and domination that impact on the lives and struggles of third world peoples." 8 The document also paid tribute to past third world international legal scholars by stating that "[...] we appreciate the need to understand and engage previous and prevailing trends in third world scholarship in international law." The TWAIL Manifesto, originally published in 2003 and written by B.S. Chimni, also made history an essential tool for the TWAIL project. His insistence on the usage of the term "third world" is justified by the fact that "once the common history of subjection to colonialism, and/or the continuing underdevelopment and marginalization of countries of Asia, Africa and Latin America is

6 BS Chimni, "The World of TWAIL: Introduction to the Special Issue" (2011) 3 Trade L \& Dev 14 at 21 [Chimni, "World of TWAIL"].

7 On TWAIL's reliance on the history of international law, see Rémi Bachand, "Les Third World Approaches to International Law: Perspectives Pour une Approche Subalterniste du Droit International" in Toufayan, Tourme-Jouannet \& Ruiz Fabri, supra note 2 at 404-407.

8 For the transcription of the 1997 TWAIL Vision Statement, see Karin Mickelson, "Taking Stock of TWAIL Histories" (2008) 10 Intl Community LR 355 at 357. [Mickelson, "TWAIL Histories"]

$9 \quad$ Ibid at 358. 
attached sufficient significance, the category 'third world' assumes life."10 And in Makau Mutua's comment on the Annual Meeting of the American Society of International Law-named "What is TWAIL?"- the past (and the present) of domination is highlighted in the first of TWAIL's objectives, which is "to understand, deconstruct, and unpack the uses of international law as a medium for the creation and perpetuation of a racialized hierarchy of international norms and institutions that subordinate non-Europeans to Europeans."11

The need for history is an essential (and, I would add, original) part of the uniqueness of TWAIL's perspective on international law. However, more than using history as an epistemological tool, TWAIL's self-image has strongly relied on a certain interpretation of how different generations of international lawyers concerned with the situation of third world peoples and states have coped with issues such as imperialism, colonialism, economic and social disparities, development, etc.

In an article dated 2003, Antony Anghie and B.S. Chimni proposed a distinction between what they call the previous and the current generation of TWAIL. The history of TWAIL was thus divided into TWAIL I and TWAIL II, although they do not identify precisely when TWAIL I began and finished. ${ }^{12}$ The piece was first published in the Chinese Journal of International Law, ${ }^{13}$ although it was originally written for a book that would be published by the American Society of International Law on different methods in international law. In 1999, the American Journal of International Law published a Symposium on Method in International Law, where TWAIL was omitted. The book on methods later corrected such omission by adding a chapter on TWAIL. ${ }^{14}$ A brief history of the article is important to know because the target of the piece was to present TWAIL in comparison with other methods available in international legal scholarship. And the book would be a repository for different methods in international law.

Anghie and Chimni recognize there were positions in TWAIL I that influenced TWAIL II. ${ }^{15}$ In other words, they realize there are continuities between generations. First, the so-called colonial international law legitimizes "the subjugation and oppression of Third World People." Second, international law was not unfamiliar to third world people before colonization; they had developed rules on the law of treaties or the law of war. Third, despite the end of formal colonization, TWAIL I scholars believed in the power of international law to transform the world for the good of the newly independent states. Fourth, TWAIL's first generation put great importance on principles of the sovereign equality of states and non-

10 BS Chimni. "Third World Approaches to International Law: A Manifesto" (2006) 8 Intl Community LR 3 at 5.

11 Makau Mutua, "What is TWAIL?" (2000) 94 Proceedings of the Annual Meeting (Am Soc of Intl L) 31 at 31.

12 However, they give an idea of the people that belong to TWAIL I. Georges Abi-Saab, F Garcia Amador, RP Anand, Mohammed Bedjaoui, and Taslim O Elias are explicitly mentioned, as well as some Western scholars sympathizers to third world positions, such as CH Alexandrowicz, Richard Falk, Nico Schrijver and PJIM de Waart. As well, they provide a long list of works that pioneered third world international legal studies. See Antony Anghie \& BS Chimni, "Third World Approaches to International Law and Individual Responsibility in Internal Conflicts" (2003) 2 Chinese J Intl L 77 at 79-84.

13 Ibid. It is important to note that, different from Anghie and Chimni, some authors refer to TWAIL I and TWAIL II to describe not generations, but different TWAIL conferences, beginning with the aforementioned Harvard gathering. See, e.g., Gathii, supra note 1 at 32 .

14 The book was published in 2004. See Steven Ratner \& Anne-Marie Slaughter, eds, The Methods of International Law (Washington: American Society of International Law, 2004).

15 Anghie \& Chimni, supra note 12 at 79-82. 
intervention. Fifth, TWAIL I also emphasized the correction of unjust economic structures, as political independence by itself could not lead to liberation.

Although they found these continuities, Anghie and Chimni put more emphasis on the differences between both generations. Differently from TWAIL I, TWAIL II establishes a critical stance on the idea of state sovereignty because "[t]his view of the transcendent post-colonial state prevented a focus on the violence of the state at home." ${ }^{16}$ Consequently, the second generation heavily weighs its analysis on individuals, especially those that suffer from deprivations.

For Anghie and Chimni, another difference between generations is related to the importance attributed by TWAIL II to theoretical inquiry. For those scholars, colonialism is in the birth of international law itself. For example, universality, a basic tenet of contemporary international law, was only achieved through the colonial encounter. Thus, differently from TWAIL I, which uncritically made use of the techniques available in international law, TWAIL II is much less enthusiastic about its emancipatory potential. ${ }^{17}$

A third difference between TWAIL I and TWAIL II is the emphasis the latter gives to the concept of the civilizing mission. It is the civilizing mission that shapes the relationship between the West and the Third World and justifies measures of intervention by powerful states and the coining of terms such as "development", "good government" and "human rights". ${ }^{18}$

Another important difference highlighted by Anghie and Chimni is the one related to the politics of knowledge. TWAIL II scholars identify a chasm between Northern and Third World scholars and institutions. Knowledge is produced and reproduced in a way to exclude the third world. This is what explains the difficulty of TWAIL scholars to become the mainstream in international legal scholarship. ${ }^{19}$

Current TWAIL scholars have generally accepted the splitting of TWAIL into two generations. ${ }^{20} \mathrm{~A}$ few have proposed the identification of a third generation (TWAIL III), emerging after September 11, $2001{ }^{21}$ This generation would have changed its focus from individuals back to states due to the centrality of issues relating to global security and terrorism on the international agenda. However, this proposal of division of generations has not yet been accepted by the majority of TWAIL's literature.

A preliminary aspect we must be aware of while coping with this issue is that TWAIL I never existed under the label "third world approaches to international law." Rather, it was invented. As Eslava and Pahuja once noted, scholars from TWAIL I and TWAIL II were united "ex post factum.,"22 Such an

$16 \quad$ Ibid at 82.

17 Ibid at 83-84.

18 Ibid at $84-86$.

19 Ibid at $86-87$.

20 See, among many, Opeoluwa Adetoro Badaru, "Examining the Utility of Third World Approaches to International Law for International Human Rights Law" (2008) 10 Intl Community LR 379; Luis Eslava \& Sundhya Pahuja, "Between Resistance and Reform: TWAIL and the Universality of International Law" (2011) 3 Trade L \& Dev 103; Vikrant Dayanand Shetty, "Why TWAIL Must not Fail: Origins and Applications of Third World Approaches to International Law” (2012) 3 King's Student LR 67; and Balakrishnan Rajagopal, "International Law and its Discontents: Rethinking the Global South" (2012) 106 Proceedings of the Annual Meeting (Am Soc of Intl L) 176.

21 Madhav Khosla, "The TWAIL Discourse: The Emergence of a New Phase" (2007) 9 Intl Community LR 291.

22 Eslava \& Pahuja, supra note 20 at 104. 
invention is not a problem in itself. Many intellectual movements have done the same. ${ }^{23}$ However, such a move brings consequences that are not easy to solve. Its intention was to, paradoxically, highlight strong discontinuities and continuities between generations. It looks to the past for authority, but at the same time, wishes to depart from it. Generations are essentially confined in time: they emerge as easily as they fade away. The passing of time, in the dynamics of generations, is inescapable.

At least four problems can be seen arising from the division of TWAIL in two generations: anachronism, progress, previous generations' self-identification as TWAILers and the image made of TWAIL by "outsiders".

\section{A. Anachronism}

In the characterization of TWAIL I, TWAIL scholars barely go into the specificities that characterized the thinking of the first generation of third world legal scholars. For example, in-depth studies on those scholars are scarce. ${ }^{24}$ Generally, their ideas are presented in a general fashion and the nuances of their scholarship are forgotten. The problem with such an approach is that the meaning of TWAIL I is presupposed rather than grasped in its richness. Were all third world legal scholars of the 1950 s or 1960 s focused on the centrality of the state in international legal scenarios? Had those scholars the epistemological tools to envisage international law as a by-product of the colonial encounter? Could their scholarship be seen as an indirect contestation of the then current politics of knowledge in international law? These are questions that can only be properly answered with a broad analysis of the contexts in which those past scholars were working within. Failing to do this often means past authors are seen as human beings that think and act in the present. TWAIL I can hardly be considered a contester of TWAIL II because many times its authors intended to provide answers to different questions than scholars of TWAIL II do. In other words, by splitting TWAIL in two, many scholars tend to incur what philosophers and theoreticians of history call anachronism.

An anachronistic reading of the past happens when someone "ascribes beliefs and intentions that presuppose modes of presentation and types of description unavailable to a certain agent at a certain time." 25 More specifically, the approach toward TWAIL I can fall into what is described as "the historical fallacy of historical teleology," in which "the precursor concept provided not only retrospective continuity; it may also furnish legitimacy, much like the practice of 'reading one's own views into a sacred text so one can read them back out endowed with authority’."26

23 For example, members of the so-called Chicago School of Sociology read past authors in order to build a bridge between past and present and foster a sense of unity among them all. For a detailed narrative of such a move, see Andrew Abbott, Department and Discipline: Chicago Sociology at One Hundred (Chicago: University of Chicago Press, 1999).

24 One of the few exceptions is the "Periphery Series" of the Leiden Journal of International Law, which devoted a substantial part of an issue to articles on the thinking of Taslim Elias. This series, however, seem to be discontinued. See "Periphery Series: Tasilim Olawale Elias" (2008) 21 Leiden J Int'1 L 289.

25 Carlos Spoerhase \& Colin G King, Historical Fallacies of Historians in Aviezer Tucker, ed, A Companion to the Philosophy of History and Historiography (London: Blackwell, 2011) 274 at 275.

26 Ibid. 
Although anachronism was condemned at some junctures, ${ }^{27}$ a few voices in recent scholarship have contested such condemnation. This is the case of two recent writings by Anne Orford. ${ }^{28}$ One of the main motivations for Orford's attack on the idea of not falling into anachronism in the domain of law seems to be at the core of a fundamental book for the TWAIL movement: Imperialism, Sovereignty and the Making of International Law, by Antony Anghie. ${ }^{29}$ In recent years, Anghie's theses have been challenged and strongly contested by some professional historians and philosophers. They contend, for example, that Anghie falls into anachronism by putting Francisco de Vitoria in an improper historical context. ${ }^{30}$

Orford reputes the relevance current historians give to anachronism to the widespread influence of the so-called contextual method supported by Quentin Skinner. While showing sympathy towards contextualism, she questions a strict acceptance of such a method since even among his peers Skinner is contested for not taking into account other contexts that influence a certain author rather than his or her own. But her main argument relies on a necessary division between legal and historiographical methods. For her, "[i]nternational legal scholarship is necessarily anachronic, because the operation of modern law is not governed solely by a chronological sense of time in which events and texts are confined to their proper place in a historical and linear progression from then to now." So, "the study of international law requires attention to the movement of meaning." ${ }^{31}$ For her, law brings two ideas of time. It operates in a specific context but also beyond it in the usage people from different ages make of it. ${ }^{32}$ Orford argues the demarcation of spaces for law and history was there even in the writings of the first generation of TWAIL scholars since they put "the development of law squarely within a historical context that had to be grasped if law was to continue to be just and effective." ${ }^{\prime 3}$

Martti Koskenniemi, in an article on Vitoria, came in defense of Anghie and developed some of Orford's arguments. Although he recognizes the value of contextualism, he finds some flaws in it. Two deserve to be stressed. The first is the difficulty in delimitating a given context. Vitoria's writings

27 See e.g., George RB Galindo, "Martti Koskenniemi and the Historiographical Turn of International” (2005) 16 EJIL 539; and Randall Lesaffer, "International Law and its History: The Story of an Unrequited Love" in Matthew Craven, Malgosia Fitzmaurice \& Maria Vogiatzi, eds, Time, History and International Law (Leiden: Martinus Nijhoff, 2007) 27. Anne Orford, "On International Legal Method" (2013) 1 London Rev Intl L 166 [Orford, "International Legal Method"] and Anne Orford, "The Past as Law or History? The Relevance of Imperialism for Modern International Law" in Toufayan, Tourme-Jouannet \& Ruiz Fabri, supra note 2, [Orford, "Past as Law"].

29 Antony Anghie, Imperialism, Sovereignty and the Making of International Law (Cambridge: Cambridge University Press, 2005).

30 In Cavallar's words, "Anghie makes fanciful connections between the sixteenth-century theologian Vitoria and the secularized discipline of nineteenth-century international law-when key concepts and approaches were civilization, race, sovereignty, state will and legal positivism, all of them rather alien to Vitoria's natural-law thinking." Georg Cavallar, Imperfect Cosmopolis: Studies in the History of International Legal Theory and Cosmopolitan Ideas (Chicago: University of Chicago Press, 2011) at 36. See also Ian Hunter, for whom: "The conception of state sovereignty that critical historiography makes central to its account of the ideological origins of European imperialism [...] was simply not present in early modern jus gentium." Ian Hunter, "Global Justice and Regional Methaphysics: On the Critical History of the Law of Nature and Nations" in Shaunnagh Dorsett \& Ian Hunter, eds, Law and Politics in British Colonial Thought: Transpositions of Empire (London: Palgrave Macmillan, 2010) 11 at 20.

31 Orford, "International Legal Method", supra note 28 at 175.

32 Ibid at 176.

33 Orford, "Past as Law", supra note 28 at 109. 
belonged to several contexts at the same time: international law would be one, but dogmatic theology or ecclesiastical matters regarding counter-reformation would be others. Besides that, the reception of his writings by later generations would put them in a number of different contexts - in a way that longue durée studies would be necessary to grasp their meaning. The second flaw has to do with relativism and anticriticism. By isolating the context from the present, any judgment of the past-including its reassessment in the light of current priorities - is to be avoided. For Koskenniemi, there is no way to detach the historian (who lives in the present) from the author (who lived in the past) he or she studies. In this sense, there is no escape, even for historians, from anachronism. ${ }^{34}$

Orford and Koskenniemi have a very good point in putting the spotlight on the limitations of contextualism and its reliance on the idea of anachronism. And Koskenniemi's article has an enormous value in identifying that the writings that motivated his own and Orford's attack on anachronism are not effective. Anghie seems not to fall into anachronism because, in Koskenniemi's words, "Anghie is just as contextual as his critics - though the context (European colonialism) is different from that chosen by the latter (16th century Spain)." 35 Yet, it is this finding that makes the claim of anachronism still important in (international legal) history.

Certainly one author may be found in different contexts during his lifetime. You can also say he or she can be inserted into a context that spreads over time. But the need for avoiding anachronism is not about being relativistic or rejecting the subjectivity dimension that informs the historian's craft.

It was Quentin Skinner himself who tackled relativism. In his words: “[u]nlike the relativist, I am not trying to offer a definition of truth. I am not in general talking about truth; I am talking about what different peoples at different times may have had good reasons by their lights for holding true, regardless of whether we ourselves believe that what they held true was in fact the truth." 36 Identifying a given context does not mean the present is better or worse than that past; it means only they are not the same and, in many respects they differ from each other. And of course the context in which the historian is inserted affects the way he or she approaches the past. No good historian can deny this. But it is also undeniable that the present context can never be the past context.

An anachronistic interpretation of the past ascribes intentions and beliefs to someone who did not have them or could not even suppose having them. Thus, finding a context is essential to understand what those intentions and beliefs were. Quite different is what different authors from later generations think about the intentions and beliefs of an author from the past. Though we may entangle them in our narratives, these two moments are quite distinct. The first deals with intentions and beliefs of a given author, the second with the interpretation of those intentions and beliefs by others.

The contextual method has its problems, ${ }^{37}$ but not taking into account the movement of ideas in time does not seem to be one of them. That is why Orford's proposal of rigidly separating the legal method and historiographical method seems not to be the best solution for future international legal scholarship:

34 Martti Koskenniemi, "Vitoria and Us: Thoughts on Critical Histories of International Law" (2014) 22 Rechtsgeschichte 119 at $123-129$.

35 Ibid at 128.

36 Quentin Skinner, "Interpretation, Rationality and Truth" in Visions of Politics: Vol. 1: Regarding Method (Cambridge: Cambridge University Press, 2002) 27 at 52.

37 The concept of meaning is one among many. On this issue, Mark Bevir, The Logic of the History of Ideas (Cambridge: Cambridge University Press, 1999) at 31-77. 
it does not consider the potential of contextualism. But it also does not realize other historiographical methodologies that are explicitly very sensitive to the present and to the movement of ideas.

One of those is textualism, which is very close to deconstructionist readings of history and is sometimes accused of presentism. ${ }^{38}$ Dominick LaCapra, an American historian associated with textualist ideas, more than thirty years ago warned against a "purely documentary" reading of the past. The alternative to that reading, however, is not the opposite: "the futile attempt to escape the past or to identify it through projection with the present." ${ }^{39}$ For him, we should dialogue with texts, and this presupposes "the past has its own 'voices' that must be respected, especially when they resist or qualify the interpretations we would like to place on them." ${ }^{.40}$

One of the biggest challenges of international legal scholarship is to overcome parochialism and establish a prolific dialogue with other disciplines, such as history. Of course, this must be done without losing the specificities of law. However, law has so much in common with disciplines from the social sciences that a dialogue is even necessary. Ironically, in the 1970s and 1980s, intellectual historiansled by Quentin Skinner, John Pocock, Dominick LaCapra and others-faced accusations of subverting the field by referring to disciplines such as linguistics, anthropology, psychoanalysis or sociology. At that moment, they were more concerned with transposing disciplinary boundaries than reasserting them. ${ }^{41}$ In many ways, modern discussions on anachronism were only viable because of the critique against (intellectual) history's methodological and theoretical self-sufficiency.

But the criticism against the concept of anachronism in international legal history can also play a problematic role in what relates to the history of TWAIL qua movement. In order to be recognized as an influential movement, TWAIL needs to build a strong link between its past and its present. This can be much better achieved with coherence, with a narrative that is firmly grounded on what past authors did and intended to do in the past. The self-image of the movement is sustained by such coherence, which is the source of its legitimacy in relation to other competitors' approaches or theories.

Falling into anachronistic readings of the past is as political as avoiding them. By establishing coherent differences between the past and the present-their continuities and discontinuitiesnonanachronistic readings of the past can open possibilities for building the future. But if expectations are so detached from experiences, to use Koselleck's two main categories to understand modern history, ${ }^{42}$ we have an anticipated future, a future that is made present. What is within the politics of

38 See e.g. David Harlan, "Intellectual History and the Return of Literature" (1989) 94 Am Hist Rev 581 at 594.

39 Dominick LaCapra, "Rethinking Intellectual History and Reading Texts" in Rethinking Intellectual History: Texts, Contexts, Language (Ithaca: Cornell University Press, 1983) 23 at 63.

$40 \quad$ Ibid at 64.

41 A good recollection of this interdisciplinary movement in intellectual history is Elizabeth A Clark, History, Theory, Text: Historians and the Linguistic Turn (Cambridge, MA: Harvard University Press, 2004).

42 Reinhart Koselleck, "'Space of Experience' and 'Horizon of Expectation': Two Historical Categories” in Futures Past: On the Semantics of Historical Time (New York: Columbia University Press, 2004) 255 at 263. 
avoiding anachronism is the opening of possibilities and different futures. ${ }^{43}$ In this way, avoiding anachronism is for and not against critique. ${ }^{44}$

\section{B. Progress}

A problem very much related to anachronism is that of progress. It also deals with the politics of time in TWAIL's own history.

It is not rare, in the writings of some TWAILers, to find the idea that the strategies and general agenda of TWAIL II is an improvement in relation to those of TWAIL I. That seems to be the case in some of Chimni's writings. He states TWAIL II has found what he characterizes as gaps in TWAIL I, something that must be overcome. ${ }^{45}$ Also, the idea of evolution plays a role in the historical narrative of the movement, sometimes explicitly. For Eslava and Pahuja, for example, who deploy the word "evolution", TWAIL II can be seen as an improvement, in epistemological terms, in relation to TWAIL II since now international law is growingly seen as part of the problem in international relations, something that was not apprehended by the first generation. ${ }^{46}$

The ideas of improvement and evolution immediately lead us to the idea of progress. By progress, I mean "a clear objective determination of direction," as a concept "simultaneously tied to standards of value (progress towards something which is subjectively better)."47

The division of TWAIL in two can be described as an "ascending periodization," which is a narrative of progress that is created "by cutting the history of international law into two or more periods and giving the most recent period the most favourable label." 48 In this case, the cutting relates to TWAIL's own history and the succession of time (TWAIL I, TWAIL II). Without proper contextualization of the past, such cutting tends to label the second generation as modernizers or reformers of the establishment.

Such a progressive approach, although trying to stress the specificities of TWAIL, risks falling into a mindset that TWAILers have been essential in criticizing in international legal scholarship. ${ }^{49}$ For example, the simple but powerful idea that " $[\mathrm{t}] \mathrm{h}$ e end of formal colonialism, while extremely significant, did not result in the end of colonial relations" $" 50$ is an important reassurance that we can often find in the present as only an appearance that social relations are better than the past in terms of achieving greater

43 Koskenniemi realized this by explicit reference to Koselleck's categories. However, such categories did not make him less critical of the concept of anachronism. See Koskenniemi supra note 34, at 123.

44 Here I follow Scott's idea of critical writing history as the point "to make visible blind spots in order to open a system to change." Joan W. Scott, "History-writing as critique" in Keith Jenkins, Sue Morgan \& Alun Munslow, eds, Manifestos for History (Oxon, UK: Routledge, 2007) 19 at 23.

45 Chimni, "World of Twail"supra note 6 at 19-20.

46 See Eslava \& Pahuja, supra note 20 at 117.

47 Erwin Faul, "Origins, Development and Crisis of the Idea of Progress" (1985) 31 L \& St 7 at 13.

48 Tilmann Altwicker \& Oliver Diggelmann, "How is Progress Constructed in International Legal Scholarship?” (2014) 25 EJIL 425 at 432.

49 Thomas Skouteris is right in identifying in TWAIL an important source for the critique against the ideology of progress in international legal scholarship. See Thomas Skouteris, The Notion of Progress in International Law Discourse (The Hague: TMC Asser Press, 2010) at 26-38.

50 Antony Anghie, "The Evolution of International Law: Colonial and Postcolonial Realities" (2006) 27 Third World Q 739 at 748-749. Despite the title, Anghie seems to use the word evolution with no connotation in terms of progress but rather simply in terms of the passing of time. 
space for freedom or equality for human beings. Or the unveiling of the Bush Administration's rhetoric about the inauguration of a new era in international relations after September 11 as a new "technology of imperialism" is aptly critical of progressive ascending periodizations. ${ }^{51}$

One of the greatest problems with progress is that it is an ideology that aims to control nothing less than time itself. By stating the present is better than the past, it gives to previous generations no more than an instrumental role in present generations. Maybe it is not possible to escape from this ideology. However, being aware of it and its consequences for building alternative futures is of utmost importance.

The splitting of TWAIL into two reinforces the ideology of progress because it suggests that, by dividing generations, what is useful in the past can remain and what is not must be rejected.

Some years ago, Karin Mickelson, in an elegant fashion, took note of that. For her, the distinction between TWAIL I and TWAIL II "entail[s] some degree of rejection of the past, of moving beyond a flawed and incomplete paradigm" and "implies a linear conception of the history of Third World scholarship on international law, a gradual progression towards some glorious enlightened future."

There is certainly much to learn from previous generations of third world legal scholars. We can definitely find in them different ideas about the future, ideas with as much dignity as the ones of the present generation. The ideology of progress cannot be the sole judge of the past.

\section{Previous Generations' Self-identification as TWAILers}

The splitting of TWAIL in two is normally seen only in the writings of TWAIL II scholars. Although some third world international lawyers from the previous generation are still active as academics and practitioners, their self-identification as members of TWAIL I is rarely seen.

One of the few occasions in which the first and the second generations met and discussed the current and future situation of third world international legal scholarship was at the TWAIL Colloquium, which took place in Paris in 2010. That meeting was important because it gathered scholars and practitioners not only from different generations but also those enthusiastic and skeptical about TWAIL. Among the scholars of the first generation that somehow addressed the issue of the common and different features of TWAIL I and TWAIL II, two deserve to be mentioned: Mohammed Bedjaoui, former president and judge at the International Court of Justice, and Mohamed Bennouna, current judge of the same court.

In the history of third world international legal scholarship, Bedjaoui is highly celebrated. Among his wide ranging, influential books, perhaps the best known is Towards a New International Economic Order. ${ }^{53}$ At the Paris Colloquium, Bedjaoui showed some reluctance in fully engaging the scholarship from the later generation. In fact, he does not question the division between TWAIL I and II, but he finds continuities between them. Nevertheless, he makes good use of the historical context in order to show that the first generation's targets were significantly different from TWAIL II's targets. ${ }^{54}$ At the end

51 Obiora Chinedu Okafor, "Newness, Imperialism, and International Legal Reform in our Time: A TWAIL Perspective" (2005) 43 Osgoode Hall LJ 171 at 180.

52 Mickelson "TWAIL Histories", supra note 8 at 361.

53 Mohammed Bedjaoui, Towards a New International Economic Order (Paris; New York: UNESCO; Holmes \& Meier, 1979).

54 Mohammed Bedjaoui, "Observations sur le Texte d'Antony Anghie" in Toufayan, Tourme-Jouannet \& Ruiz Fabri, supra note 2, 81 at 83 . Moreover, Bedjaoui points out a pronounced difference between generations. For him, the first 
of the piece, he suggests there is a huge-perhaps insurmountable — gap between both generations. For him, more than being colonialistic, international law is imperialistic; however, differently from the second generation, he doubts whether there is no possibility of supplanting such an imperialistic form. Some current developments (such as the emergence of BRICS), in his own vision, bring the possibility of overcoming imperialism. ${ }^{55}$ He thus considers TWAIL II as a too-pessimistic approach that opens no or only a scarce possibility for the building of a different international order through international law.

A similar attitude of "not belonging" can be found in the short (and also not very enthusiastic) comments of Mohamed Bennouna. During the 1970s and the 1980s, Bennouna's scholarship focused on issues of great importance for third world states, such as the law of the sea and the law of development. $^{56}$

After admitting he lacked, for some time, interest in third world international legal scholarship, the Paris Colloquium reminded him of the importance of such literature. However, he seemed to see the viability of TWAIL only if it dialogues with "other sensibilities", such as a so-called "critical legal humanism", which he apparently supports. ${ }^{57}$

Some important representatives of the so-called first generation of TWAILers seem very reluctant to self-identify with the agenda of the second generation. Although they are still productive practitioners and scholars, their scholarship is not grounded on the second generation's writings. If we take Bedjaoui and Bennouna as examples, their preoccupations lie with the agenda set by mainstream international lawyers. The same could be said about Georges Abi-Saab. A chronological reading of his articles on the general theory of international law-recently collected in a volume published in France-show a gradual detachment toward issues related to colonialism and postcolonialism. ${ }^{58}$

In sum, although TWAIL II scholars rely on the scholarship of the so-called TWAIL I to shape the identity of the movement, important representatives of the first generation seem not to be part of the TWAIL endeavour. They feel a lack of belonging to TWAIL.

\section{The Image Made of TWAIL by "Outsiders"}

A fourth problem of splitting TWAIL concerns the image made by those that are critical of it. In the international legal field, there are not many in-depth studies aiming to criticize the essentials of the TWAIL project. ${ }^{59}$ However, the aforementioned Paris Colloquium provided a unique opportunity for

generation accomplished a lot, such as the establishment of international organizations or international instruments. Such a statement can clearly be seen as a critique against an alleged lack of institutional engagement of the second generation. Ibid at 84 .

55 Ibid at 87-91; BRICS states are Brazil, Russia, India, China and South Africa.

56 See e.g. Mohamed Bennouna, Droit International du Développement: Tiers Monde et Interpellation du Droit International (Paris: Berger Levrault, 1983).

57 Mohamed Bennouna, "Le Tiers Monde Aujourd'hui. Bilan et Perspective" in Toufayan, Tourme-Jouannet \& Ruiz Fabri, supra note 2, 429 at $429-430$.

58 See Georges Abi-Saab, Le Développement du Droit International: Réflexions d'un Demi-Siècle. Volume 1: Théorie Générale du Droit International Public (Geneva: The Graduate Institute Publications, 2013). Abi-Saab's detachment to a certain kind of TWAIL literature - specifically that close to critical legal studies scholarship - was made explicit in his intervention at the 2015 TWAL Conference, held in Cairo.

59 There are, of course, good analyses of scholars that, although not self-identified as TWAILers, have sympathy for the movement, wishing to improve its methodological and theoretical consistency or radicalize it. See e.g. Bachand, supra 
TWAIL affiliates as well as mainstream international lawyers to reflect upon the third world and international law today. Three interventions made on that occasion are worth mentioning.

First, Olivier Corten, possibly the most acerbic critic of TWAIL in the Paris Colloquium, questioned the strategy of splitting TWAIL in terms of the newness of its arguments. For him, the naming of TWAIL I by TWAIL II is anachronistic and aims to ground the movement's identity in history. However, although TWAIL II's reliance on TWAIL I gives the former an authority to follow, it otherwise questions its originality. In fact, he seems to suggest the origins of TWAIL would not be in TWAIL I but in critical approaches to international law. Hence, there is no original methodology or epistemology in the movement. Its objectives could even be pursued by positivistic and formalistic international legal methods. With no original methodology or epistemology, TWAIL is, for him, a kind of "academic marketing." 60

In a similar fashion, Jean Salmon sees in TWAIL no specific problems or values. If many of the commonalities between TWAIL I and TWAIL II rest on the values supported by those different generations in regard to the defense of the weak, their field of application is too broad and is restricted to the third world. ${ }^{61}$ Therefore, it seems that, for Salmon, not even the identification of different generations in TWAIL gives it a precise meaning or legitimizes its aims.

Although he shares many of TWAIL's concerns, José Alvarez thinks the greatest challenges for TWAIL are internal. All evoke the sharing of the commonalities of the aims of the two generations. For him, the "third world" is a complicated concept upon which to ground a school of thought or movement. There is also confusion between TWAIL and NAIL [New Approaches to International Law], which brings some doubts about the origins of the movement. Finally, TWAIL's reliance on "suffering" is "a vague platform to be taken seriously., ${ }^{, 2}$

Considering those criticisms, the splitting of TWAIL has posed challenges for the identity of the movement and is not of great help to legitimize it within different streams of international legal thought.

\section{THE TWAIL MOVEMENT AND THE THIRD WORLD INTERNATIONAL LEGAL TRADITION}

At this point, it is essential that TWAIL give broader attention to the idea of what it represents, not only for its own affiliates and sympathizers, but also for the international legal mainstream, including its critics. The splitting of TWAIL brings problems difficult to solve and, in certain regards, has not helped to forge its own identity. Due to that, it is essential to identify what is needed for TWAIL to flourish as a unique vision of international law. In this section, I will briefly present a different way to present TWAIL's history, one that is not based on the separation of two different generations but in the finding

note 7; and John D Haskell, "TRAIL-ing TWAIL: Arguments and Blindspots in Third World Approaches to International Law" (2014) 27 Can JL \& Jur 383.

60 Olivier Corten, "Les TWAIL: Approche Scientifique Originale ou Nouveau Label Fédérateur?" in Toufayan, TourmeJouannet \& Ruiz Fabri, supra note 2, 357 at 359-366.

61 Jean Salmon, "Propos Introductifs" in Toufayan, Tourme-Jouannet \& Ruiz Fabri, supra note 2, 309 at 309.

62 José E. Alvarez, "What is to be done?" in Toufayan, Tourme-Jouannet \& Ruiz Fabri, supra note 2, 83 at 390-392. 
of a common tradition of thought with nuances and commonalities that pass through the generations. The sociology of ideas can be of great help in such an effort.

To do so, I make use of Frickel and Gross's theory of scientific/intellectual movements [SIM]. They attempt to answer the question on how SIMs "emerge, gain adherents, win intellectual prestige, and ultimately acquire some level of institutional stability". ${ }^{63}$ Following Frickel and Gross's theory, TWAIL is definitely an intellectual movement since "SIMs are collective efforts to pursue research programs or projects for thought in the face of resistance from others in the scientific or intellectual community.",64

The authors make four propositions that sustain their theory on scientific/intellectual movements, but I will focus only on the fourth since it is more directly related to the division of TWAIL into two generations. The fourth proposition is stated as follows: "The success of a SIM is contingent upon the work done by movement participants to frame movement ideas in ways that resonate with the concerns of those who inhabit an intellectual field or fields." ${ }^{65}$ By "framing" the authors mean "the processes by which SIM participants collectively represent the movement to insiders and outsiders.",66

So, the concept of framing is essential in any effort to make TWAIL (or any other intellectual movement) influential. Within this concept, ideas such as the movement's self-image, collective identity and historical origins play a key role. That is why Frickel and Gross elucidate four related dimensions of the concept of framing: (1) Intellectual identity, which means the identity of any SIM is forged on the so-called self-concepts. ${ }^{67}$ Self-concepts are "more or less stable narratives thinkers use to understand who they are as intellectuals". ${ }^{68}$ (2) Rhetorical constructions of the movement's collective identity. In this dimension, it is important to note that, despite the differences between intellectuals, it is essential for the SIM to explore key ideas, publish edited volumes and host conferences. ${ }^{69}$ These initiatives definitely forge commonalities among scholars. (3) Historical origins. In Frickel and Gross's words, "[t]he more successful movements are those that effectively frame their SIM as the natural outgrowth of and the heir to some set of values, beliefs, assumptions, and identities widely held among the intellectuals who compose its potential recruitment base, or among those who control access to key resources such as foundation funding or publication space."70 This dimension is directly related to the strategies of periodizing an intellectual movement such as TWAIL. (4) The SIM's relation to various competitor movements. It relates to the position of a certain SIM in the stock market of ideas. ${ }^{71}$

Taking into account Frickel and Gross's theoretical insights on SIMs, some short remarks can be provided on the context of TWAIL as an intellectual movement in international legal scholarship.

63 Scott Frickel \& Neil Gross, "A General Theory of Scientific/Intellectual Movements” (2005) 70 Am Soc Rev 204 at 205.

64 Ibid at 206. It is essential to note that Frickel and Gross' insights are founded in the assumption that SIMs are, in many respects, similar to social movements. Ibid at 205. If we expand the meaning of TWAIL to consider it as a social movement - something that emerges, for example, from a TWAIL literature that sees it as a counter-hegemonic and oppositional political project - their theory can also be useful.

65 Ibid at 221.

66 Ibid at 222

67 Ibid.

68 Neil Gross, "Becoming a Pragmatist Philosopher: Status, Self-Concept, and Intellectual Choice” (2002) 67 Am Soc Rev 52 at 53.

69 Frickel and Gross, supra note 63 at 223.

$70 \quad$ Ibid at 223.

71 Ibid at 224. 


\section{A. A Conflict of Identities}

The splitting of TWAIL into two makes it explicit for insiders and outsiders that there is a conflict of identities: one from the first and another from the second generation. The source of discomfort with TWAIL in the members of the first generation is probably due to an incomplete reading by TWAIL II of their accomplishments or the lack of in-depth narratives about how international lawyers, during the decolonization years, acted in and thought about the international legal scenario. Recently, studies on that period have emerged, but much more needs to be done. ${ }^{72}$

In order to tackle such conflict, it is essential that TWAIL keeps forging its own identity through the enforcement of self-concepts that can be found, again, through in-depth historical narratives of the first as well as of the second generation of third world legal scholars.

Some of those self-concepts are already being identified by TWAIL scholars, though not with emphasis on what is shared with the first generation. Take resistance as a possible self-concept. Rajagopal has been lucidly insisting on its centrality for the TWAIL project. In a relatively recent writing, he even suggests "resistance posed by the people of the former colonies" was what animated the critique against colonialism and its variants, and is a possible common ground for TWAIL I and TWAIL II. ${ }^{73}$ But there are also other possible self-concepts. Eslava and Pahuja have mentioned reformer and universalist ${ }^{74}$ and we could also add "contester of the status quo" or "anti-imperialist" as possible selfconcepts. $^{75}$

In any case, those self-concepts will not necessarily remain the same; however, if they are so detached from the first generation's self-concepts, a common ground between generations will fade away. In different terms, Karin Mickelson seems to point out such ideas by stating a methodological specificity of TWAIL is still an open question. It is open because TWAILers "have remained determinedly eclectic in their theoretical and methodological inspirations." While diversity must be praised, there is also a need for "some unifying core for the movement as a whole." 76 And such a unifying core should take time seriously by stimulating the historical research of the first generation of third world legal scholars.

72 Here, the books by Pahuja and Fakhri might be recalled. See Sundhya Pahuja, Decolonising International Law: Development, Economic Growth and the Politics of Universality (Cambridge: Cambridge University Press, 2011) and Michael Fakhri, Sugar and the Making of International Economic Law (Cambridge: Cambridge University Press, 2014). A book on the Bandung Conference, about to be published by Cambridge University Press, will definitely be a great contribution to the building of good narratives on third world international legal scholarships in the past.

73 Rajagopal, supra note 20 at 176.

74 Eslava \& Pahuja, supra note 20 at 115-122.

75 Related to idea of finding self-concepts is what philosophers and theorists of history call colligation. A colligation is an operation in which historians aim to "display a pattern they have discerned among events in the past, a pattern which gives each of those events meaning and significance, and which sometimes helps to explain them." C. Behan McCullagh, "Colligation" in Aviezer Tucker, ed, A Companion to the Philosophy of History and Historiography (London: Blackwell, 2011) 152 at 152. It is worth mentioning that finding self-concepts and colligating events of the past poses a risk in terms of making the historian or the international lawyers fall into anachronism. This is something that can only be avoided with good historiographical research.

76 Mickelson "TWAIL Perspective", supra note 2 at $314,318$. 


\section{B. Generations and the Third World International Legal Tradition}

Periodizing TWAIL in terms of generations (I and II) creates problems difficult to solve from a historiographical point of view.

Balakrishnan Rajagopal, who is certainly one of the most influential figures in the TWAIL movement, differently from other TWAILers, situates the beginning of TWAIL I at the turn of the twentieth century, when the articulation of the Calvo and Drago doctrines, the critique of imperialism and the creation of international control for the administration of colonies emerged. ${ }^{77}$ If Rajagopal is right, there were generations of TWAILers before the 1960s, and we would be compelled to adjust the chronological beginning of TWAIL more than 60 years before or admit there were one or two generations before TWAIL - a TWAIL -1 or -2 . On the other hand, as previously noted, some authors contend that, after September 11, 2001, a new phase has emerged, that of TWAIL III. ${ }^{78}$ Moreover, it is possible there is a hidden generation, the one that lived during the 1980s and the first half of the 1990sthe time when third world international legal studies were not visible enough. This makes the generation issue a puzzle difficult to solve and, even if solvable, the solution tends to be useless.

Philosophers of history have treated the concept of generation for a long time. Originally, it has a biological-genealogical meaning in the sense that ancestors take a certain period of time to have their descendants. But more importantly is the assumption that the passing of generations has an element of continuity - the succession between parents and offspring - as well as a discontinuous element- the changes operated in the social and cultural milieu of a succeeding generation. ${ }^{79}$ Such idea of generations, despite the reference to fathers and sons, has been applied to people with intellectual affinities with others in the past.

Alternatively, the passing in time of bodies of knowledge from one group of intellectuals to another can be studied under the umbrella of tradition. Thus, tradition can be defined as "bodies of thought passed down from one intellectual generation to the next." ${ }^{" 80}$ Contemporary social sciences, however, have opted for the study of a part of a tradition "which appears in the process of acquisition, thinned down and reduced in content and narrowly confined to the relations of one generation to another." neglect of tradition is possibly due to the association of tradition with "backwardness and reactionary beliefs" as well as a "naïve view that modern society was on the road to traditionlessness, to the domination of action by 'interests' and 'power'.." 82 There is also another explanation, which has to do with the emergence of the bourgeois person, for whom everything is subordinated "to the rules of the game of the marketplace, even his alleged love for tradition and preference for the past". ${ }^{83}$

Just like generations, traditions have elements of stasis and change, continuity and discontinuity. But it is essential to note that, in a tradition, "what are thought to be the essential elements are recognizable by an external observer as being approximately at successive steps or acts of transmission and

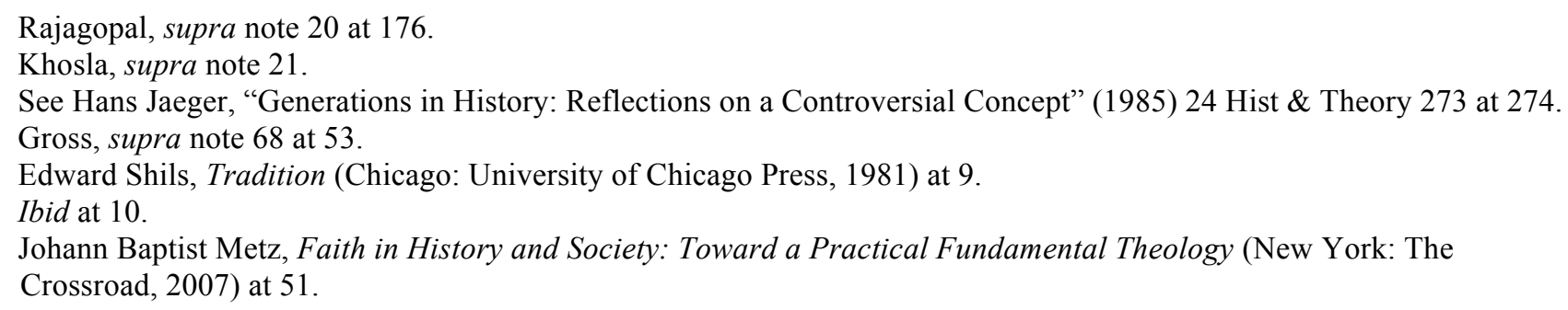


possession." ${ }^{, 44}$ In this way, it is clear continuity plays a more important role than discontinuity in identifying a tradition. The starting point for a tradition is the common features (such as self-concepts) shared by those who belong to it, bodies of knowledge that remain in time. Instead, the process of identifying a generation is much more an act of identifying discontinuities since one recognizes a generation by its differences with another generation.

It is essential to note that traditions, by their own nature, encompass a wide range of different perspectives on a single issue. Diversity and nuance are the fuel that allows a tradition to last. It brings to the table a different perspective on how time flows in the realm of ideas, realizing that there is unity within diversity - even though such unity is contingent and, in some cases, loosely framed. In order to foster a common identity between self-concepts shared by different scholars over time, TWAILers must get rid of the strong emphasis on the idea of generations; instead, they should reinforce the idea of an intellectual tradition: the third world international legal tradition. The reinforcing of a common tradition implies overcoming boundaries and finding a continuum of ideas, beliefs and values over time. The reach of that tradition is an open question. It may have started at the beginning of the decolonization process or even before, as suggested by Rajagopal. What really matters is that the people often associated with TWAIL I and TWAIL II belong to it.

This way, I think the above-mentioned continuities between TWAIL I and TWAIL II found by Anghie and Chimni may be an excellent starting point for finding a shared identity linking the different generations of TWAIL. There is a special need for scholarship to remember what the very idea of time puts together. A good historiographical research on TWAIL's own past can also find many other traits showing a continuous pattern through generations.

Besides that, tradition may be a powerful tool for engaging TWAIL politically. Framing TWAIL in an intellectual tradition can make the voices of the past heard more carefully, as the emergence of a new generation will not be a sufficient cause to forget or bypass them. In other words, the focus on tradition could be of great help in TWAIL's commitment to think about international law through historical lenses.

It can also be added that speaking about a third world international legal tradition is not a brand new idea. Already in 2008 Karin Mickelson characterized TWAIL "as a part of a Third World tradition of international law scholarship rather than the overarching framework into which all Third World scholarship can be fit." ${ }^{85}$ In fact, even before that, her analysis of the meaning of a third world approach to international law indistinctively encompassed scholars from the 1950 s to the $2000 \mathrm{~s} .{ }^{86}$

Inserted into a tradition of thought, TWAIL is better seen as an intellectual movement in the sense of Frickel and Gross. It commenced precisely at the end of the 1990s, with the aforementioned Harvard Law School Seminar. ${ }^{87}$ Identifying a beginning for TWAIL as a movement is essential since its specificities can barely be applied to the scholars and practitioners of the 1960s, despite the fact that it

Ibid at 14.

85 Mickelson "TWAIL Histories", supra note 8 at 362.

86 See Karin Mickelson, "Rhetoric and Rage: Third World Voices in International Legal Discourse" (1998) 16 Wis Intl LJ 353.

87 Mickelson is clear in situating the TWAIL qua movement around 1997 and not in the 1960s (or before), differentiating it from "a broader stream of Third World engagement with international law." Mickelson "TWAIL Histories", supra note 8 at $360-361$. 
possibly shares common features with other movements that were also included in the same intellectual tradition. $^{88}$

\section{CONCLUSIONS}

In this article, I argued the splitting of TWAIL in two is quite problematic, not only from a historiographical point of view but also from a perspective that tries to make it a more influential intellectual movement in international legal scholarship. As a result, I advanced the idea - that still is within the habit human beings have of periodizing - of regarding TWAIL as an intellectual movement inserted into an intellectual tradition. This tradition-based approach is more appropriate, I think, to overcome the aforementioned problems.

But the scholarship on splitting TWAIL must be taken very seriously. Chimni and Anghie, who first proposed the periodization of TWAIL in two generations, have an enormous merit in recollecting what past third world international legal scholars did in a coherent fashion. Such a move provoked in TWAILers a historical self-consciousness that is hardly seen in other intellectual movements in international law; any effort to refine periodization schemes would be impossible without such a move.

Commenting on the problems arising from the periodization of the end of the Soviet Union, Martin Jay, in an eloquent way, highlighted the relevance of periods "as tools of historical analysis and presentation." However, he warned, "[w] hat then becomes interesting is their interface with the lived experience of those who inhabit them, or cross what is a felt threshold from one to another." 89 The more pressing challenge of periodizing TWAIL's history is giving voice to those that, in a changing world, tried to make international law a tool to correct inequalities and alleviate the suffering of hundreds of millions of people. If this is accomplished, TWAIL will not only teach other intellectual movements in international law about the importance of history in its own self-constitution, but it will be committed to a duty we often forget in our daily lives: the duty of making the world better for those in need.

88 Anghie and Chimni once mentioned a "TWAIL I tradition" ("TWAIL II scholarship has broadly followed the TWAIL I tradition and elaborated upon it, while, inevitably, departing from it in significant ways." Anghie \& Chimni, supra note 12 at 79. Perhaps they deployed the word "tradition" in a loose way. In any case, for the purposes of this article, it is not possible to talk about a TWAIL I or a TWAIL II tradition but instead a third world international legal tradition.

89 Martin Jay, “1990: Straddling a Watershed?” in Essays From the Edge: Parerga and Paralipomena (Charlottesville: University of Virginia Press, 2011) 177 at 183. 